\author{
Tomasz Garncarek * \\ ORCID: 0000-0003-1687-3829 \\ Uniwersytet Wrocławski
}

DOI: $10.19195 / 1733-5779.27 .1$

\title{
Ryzyko braku zgodności w bankowości - compliance oraz instytucja whistleblowing
}

JEL Classification: G2, K2

Słowa kluczowe: ryzyko, brak zgodności, compliance, sygnaliści, ład korporacyjny

Keywords: risk, incompatibility, compliance, whistleblowing, corporate governance

\begin{abstract}
Abstrakt: Rozważania niniejszego artykułu skupiają się na sektorze bankowości, w ramach którego aktualnym problemem pozostaje kwestia braku zgodności z regulacjami prawa krajowego i unijnego. Wyjaśniono podstawowe pojęcie ryzyka braku zgodności wraz z omówieniem istoty działalności systemu compliance, które jest niezbędne do podjęcia dalszych rozważań na ten temat. Na przestrzeni ostatnich kilku lat obserwujemy znaczny wzrost w zakresie nowych aktów prawnych mających na celu pogłębienie regulacji systemu finansowego. W artykule analizie poddano obowiązujące akty prawne, jak również regulacje soft law odnoszące się do systemu compliance, stawiając tym samym tezę o konieczności stałego nadzoru nad aktualnością obowiązujących regulacji w stosunku do rozwoju sektora bankowego. W ostatniej części artykułu zwrócono uwagę na jeden ze środków compliance, jakim jest instytucja whistleblowingu oraz kwestię zgłaszania ewentualnych naruszeń i ochrony osoby zawiadamiającej.
\end{abstract}

\section{Compliance risk in the banking system and institutions of whistleblowing}

\begin{abstract}
Considerations of this article focus on the banking system in which the current problem is compliance risk with laws and regulations. It explains the basic concept of "compliance risk" as well as the fundamentals of the functioning of the compliance system, which are necessary for the the ensuing considerations. Over the last few years we have winessed a significant increase in new legal acts aimed at deepening the regulation of the financial system. This article analyzes existing legal acts, as well as the "soft law" regulations relating to the compliance sector, advancing a thesis on the necessity of constant supervision over the validity of binding regulations in relation to the

* Opiekun naukowy (Scientific Tutor) — prof. dr hab. Patrycja Zawadzka
\end{abstract}


development of the banking system. In the last part of the article attention was paid to one of the compliance measures, that is, the whistleblowing institution and the issue of reporting possible violations and protection of the person reporting those violations.

\section{Wstęp}

Kwestia niezgodności z szeroko pojmowanymi regulacjami (ang. compliance) pozostaje od wielu lat tematyką, do której szeroko rozumiane instytucje finansowe $^{1}$ przykładają mniejszą bądź większą wagę w zależności od zaangażowania ustawodawcy. Niewątpliwie w ostatnich latach obserwuje się chęć współpracy polskiego ustawodawcy $\mathrm{z}$ organami nadzorczymi w zakresie systematycznego wzbogacania przepisów regulujących nadzór zgodności działalności banku. Istotnym impulsem skutkującym wzmożonym zaangażowaniem podmiotów finansowych w obszarze ryzyka braku zgodności jest rozporządzenie Parlamentu Europejskiego i Rady (UE) 2016/679 z dnia 27 kwietnia 2016 roku w sprawie ochrony osób fizycznych w związku z przetwarzaniem danych osobowych i w sprawie swobodnego przepływu takich danych oraz uchylenia dyrektywy 95/46/WE ${ }^{2}$, zwane RODO. Rozporządzenie to weszło w życie 17 maja 2016 roku, jednak odroczono termin na realizację obowiązków z niego wynikających, w wyniku czego zaczęło obowiązywać bezpośrednio w krajowym porządku prawnym od dnia 25 maja 2018 roku. W ciągu ostatnich kilku lat wprowadzono akty prawne mające na celu pogłębioną regulację skutkującą wzrostem ryzyka w systemie compliance, czego wyrazem jest chociażby wprowadzenie normy ISO/DIS 19600 Compliance management systems - CMS.

Celem artykułu jest przedstawienie roli i znaczenia systemu compliance w obszarze bankowości, jak również podjęcie problematyki w zakresie eliminowania ryzyka braku zgodności poprzez instytucję whistleblowing ${ }^{3}$. Rozważania rozpoczęto od zdefiniowania samego pojęcia ryzyka braku zgodności. Zrealizowanie celu wymagało również analizy systemu compliance na podstawie regulacji prawa krajowego i unijnego, a także zwrócenia uwagi na regulacje soft law, w ramach których naruszenie wpływa na stabilność i wiarygodność systemu finansowego. W dalszej części artykułu zostanie przeprowadzona analiza skuteczności wprowadzanych regulacji prawa krajowego i unijnego, mających wpływ na potencjalne wystąpienie ryzyka braku zgodności. Bez wątpienia rozwój w obszarze syste-

${ }^{1} \mathrm{Na}$ temat pojęcia instytucji finansowej w prawie rynku finansowego zob. m.in. P. Zapadka, Definicja legalna instytucji finansowej w polskim systemie prawnym - wybrane zagadnienia, „Prawo Bankowe” 2005, nr 9, s. 90 n.; D. Cyman, Instytucja finansowa, [w:] Leksykon prawa finansowego. 100 podstawowych pojęć, red. A. Drwiłło, D. Maśniak, Warszawa 2009, s. 163-164.

2 Dz.Urz. UE L 119 z 4 maja 2016 roku.

3 Szerzej na ten temat zob. Ł. Cichy, Whistleblowing $w$ bankach, Warszawa 2017, passim; W. Rogowski, Whistleblowing: bohaterstwo, zdrada czy interes?, „Przegląd Corporate Governance" 2007, nr 1 (9), passim; J.P. Near, M.P. Miceli, Organizational Dessidence: The Case of Whistle-blowing, ,Journal of BusinessEthics” 1985, nr 4, s. 4. 
matyzacji obowiązków i uprawnień, jak również nadanie systemowi compliance właściwej rangi w strukturze wewnętrznej stanowi sedno prawidłowego zarządzania ryzykiem braku zgodności w bankowości.

\section{Istota i definicja ryzyka braku zgodności - compliance}

Mimo iż system compliance dopiero zyskuje na popularności w obszarze bankowości, można zauważyć różnorodność definicyjną w zakresie terminu „ryzyko braku zgodności”. Wydaje się, że wpływ na taką sytuację ma przede wszystkim źródło pochodzenia definicji oraz zmienność obszaru poddawanego regulacjom. Wydaje się, że problematyka w sferze definicyjnej może pojawiać się ze względu na fakt dwuczłonowości definicji składającej się z pojęcia „ryzyko” oraz „,brak zgodności”. Tego rodzaju definicje wyróżnia możliwość występowania różnych komponentów, których zdefiniowanie ma kluczowy wydźwięk w świetle znaczenia terminu „ryzyko braku zgodności”. W działalności banku wyróżnia się wiele płaszczyzn, w ramach których podejmowane czynności obarczone są ryzykiem, czego przykładem jest na przykład ryzyko płynności, ryzyko kredytowe, ryzyko instrumentów pochodnych, ryzyko nadmiernej dźwigni finansowej oraz ryzyko braku zgodności ${ }^{4}$.

W kontekście wyrażenia „ryzyko braku zgodności” pojęcie „ryzyko” definiuje się jako ryzyko sankcji prawnych, $w$ tym regulaminowych, utrata dobrej reputacji bądź straty finansowe. Wspomniane konsekwencje są wynikiem niestosowania się do ustaw, rozporządzeń, innych przepisów prawnych, jak również obowiązujących standardów i kodeksów postępowania przyjętych w bankowości ${ }^{5}$. W znaczeniu materialnym termin compliance należy definiować jako stan zgodności działania podmiotu z mającymi w stosunku do niego zastosowanie szeroko pojmowanymi regulacjami w formie zarówno aktów prawnych, jak i wewnętrznych zaleceń ${ }^{6}$.

Na wspomnianych płaszczyznach może wystąpić zjawisko wtórnego ryzyka legislacyjnego, polegające na braku zgodności wewnętrznych poczynań banku z obowiązującymi przepisami prawa i unormowaniami regulatorów ${ }^{7}$. Wówczas można wskazać sytuację, w której brak zgodności pojawia się przy niewłaściwym wykonywaniu czynności bankowych, nieprawidłowych konstrukcjach umów cywilnoprawnych z dostawcami i klientami banku oraz pracownikami i członkami

${ }^{4}$ Zob. Dz.Urz. UE L 176 z dnia 27 czerwca 2013 roku, s. 381-383.

5 Ł. Cichy, Funkcja compliance w bankach, Warszawa 2015, s. 7.

${ }^{6}$ B. Jagura, Rola organów spółki kapitałowej w realizacji funkcji compliance, Warszawa 2017, s. 32; B. Jagura, T. Szarowicz, Prawne podstawy systemów zarządzania compliance $w$ prawie niemieckim i polskim, „Controlling” 2014, nr 3-4, s. 15.

7 C. Paluchniak, Definicja ryzyka prawnego w bankowości oraz krytyczna ocena rekomendacji H Komisji Nadzoru Finansowego, „Nauki o Finansach” 2015, nr 3, s. 184. 
organów banku, jak również poprzez stosowanie niewłaściwych wewnętrznych procedur niedostosowanych do obowiązującego prawa ${ }^{8}$.

W dokumentach sporządzanych przez banki i instytucje kredytowe ryzyko braku zgodności jest rozumiane jako ryzyko, z którym wiąże się powstanie strat finansowych, obciążenie sankcjami prawnymi bądź utratą reputacji wskutek niezastosowania się grupy kapitałowej, pracowników grupy kapitałowej lub podmiotów działających w jego imieniu do obowiązujących przepisów prawa, regulacji wewnętrznych, jak również zatwierdzonych przez grupę kapitałową standardów rynkowych ${ }^{9}$. Takie ujęcie jest odzwierciedleniem pojęcia compliance $\mathrm{w}$ znaczeniu formalnym, przez co należy rozumieć szeroko definiowany system zarządzania compliance, czyli organizację compliance, jak również całe spektrum środków mających zapewnić compliance właśnie w tym znaczeniu ${ }^{10}$.

Ponadto w literaturze naukowej wskazuje się na pojęcie Compliance Management System, które jest odzwierciedleniem systemowego podejścia do kwestii zarządzania ryzykiem braku zgodności poprzez wprowadzenie mechanizmu compliance na szczeblu wszystkich procesów występujących w danej organiza$\mathrm{cji}^{11}$. Z kolei termin Compliance Management System jest definiowany jako zbiór wprowadzanych przez organizację norm oraz założeń dotyczących jej polityki, jak również podjętych w organizacji działań zmierzających do eliminowania ryzyka braku zgodności poprzez zapewnienie przestrzegania przepisów prawnych i standardów etycznych ${ }^{12}$.

Niewątpliwie do rozwoju systemu compliance w szerszej perspektywie przyczynił się dorobek takich dyscyplin naukowych, jak: ekonomia, zarządzanie, prawo, filozofia, psychologia, co potwierdza jego interdyscyplinarny charakter ${ }^{13}$. W literaturze przedmiotu system compliance jest definiowany jako obszar odpowiadający za identyfikację czynności wpływających na wystąpienie zagrożenia związanego z niewłaściwym wykonywaniem czynności bankowych, nieprawidłową konstrukcją umów cywilnoprawnych z klientami banku oraz pracownikami

8 R. Jakubowski, Rozwój funkcji compliance w polskim sektorze bankowym, ,Monitor Prawa Bankowego” 2013, nr 11, s. 63-65; B. Zdanowicz, Compliance - nowa funkcja banków, „Bezpieczny Bank" 2004, nr 1 (22), s. 81.

9 Zob. sprawozdanie zarządu z działalności Grupy Kapitałowej PKO Banku Polskiego SA za 2015 rok, https://www.pkobp.pl/media_files/18d10e93-dd69-4ab7-8839-0fa406cc4343.pdf(dostęp: 24.09.2018).

10 J. Pape, Corporate Compliance - Rechtspflichten zur Verhaltenssteuerung von Unternehmensangenhorigen in Deutshland und den USA, Berlin 2011, s. 22.

11 A. Barcik, Mechanizm compliance - pytanie o miejsce i zasadność w strategiach csr wspótczesnych organizacji, „Prace naukowe Uniwersytetu Ekonomicznego we Wrocławiu” 2016, nr 419, s. 15.

12 S. Bleker, D. Hortensius, ISO 19600: The development of a global standard on compliance management, „Business Compliance”, 2014, nr 2.

13 B. Makowicz, Compliance w przedsiębiorstwie, Warszawa 2011, s. 15-20. 
i członkami organów banku, jak również niewłaściwie ustanowione wewnętrzne procedury niedostosowane do obowiązujących przepisów prawnych ${ }^{14}$.

W literaturze przedmiotu system compliance określa się również jako zbiór środków mających na celu zapewnienie przestrzegania prawnych nakazów i pozostawania w reżimie ustawowych zakazów w stosunku do przedsiębiorstw, członków poszczególnych organów przedsiębiorstw, jak również jego pracowników ${ }^{15}$. W tym ujęciu system compliance pełni również funkcję ochronną instytucji finansowych ze względu na to, że oprócz zażegnania potencjalnych strat materialnych odpowiada za straty w zakresie utraty reputacji.

$\mathrm{Na}$ gruncie prawa europejskiego podjęto działania mające na celu efektywniejsze wdrożenie systemu compliance w ramach struktury Unii Europejskiej, chociażby poprzez sporządzenie wytycznych w zakresie eliminacji potencjalnego ryzyka braku zgodności. W wydanym przez Komisję Europejską dokumencie Compliance matter. What companies can do better to respect EU competition rules ${ }^{16}$ system compliance zdefiniowano jako zbiór zasad i przepisów proceduralnych wdrażanych przez przedsiębiorstwo, które określały wymogi względem pracowników w zakresie podejmowania czynności zgodnych z prawem konkurencji, w szczególności na gruncie regulacji antykartelowych, oraz tworzących system kontroli jego przestrzegania i wykrywania jego naruszeń.

Z kolei w dokumencie konsultacyjnym Compliance and the Compliance Function in Banks ${ }^{17}$ wydanym przez Komitet Bazylejski Nadzoru Bankowego ${ }^{18}$ określono rolę, jaką funkcja compliance odgrywa w strukturze bankowości. W myśl dokumentu konsultacyjnego:

Na podstawie delegacji Zarządu Departament Compliance jest odpowiedzialny za zarządzanie ryzykiem sankcji prawnych, regulacyjnych, straty finansowej oraz reputacji, jakie bank może ponieść w wyniku nieprzestrzegania przepisów prawa, regulacji, zasad, standardów właściwych organizacji oraz kodeksów postępowania, obowiązujących w działalności bankowej.

W szerokim ujęciu ryzyko braku zgodności odnosi się do całokształtu funkcjonowania systemu kontroli wewnętrznej, który stał się obowiązkiem wszystkich

14 R. Jakubowski, op. cit., s. 63-65; B. Zdanowicz, op. cit., s. 81.

15 U. Schneider, Compliance als Aufgabe der Unternehmensleitung, Zeitschrift für Wirtschaftsrecht und Insolvenzpraxis, ZIP 2003, s. 645-650.

${ }^{16}$ Compliance matter. What companies can do better to respect EU competition rules, European Commission. Competition, Special first edition, Belgium 2011, https://publications.europa. eu/en/publication-detail/-/publication/78f46c48-e03e-4c36-bbbe-aa08c2514d7a/language-en (dostęp: 24.09.2018).

17 https://www.bis.org/publ/bcbs103.htm (dostęp: 15.09.2018).

18 Basel Committee on Banking Supervison (BCBS) — Komitet Bazylejski ds. Nadzoru Bankowego powstał w 1974 roku pod auspicjami Banku Rozrachunków Międzynarodowych (BIS). Komitet Bazylejski stanowi forum współpracy państw członkowskich w zakresie nadzoru bankowego. Nie pełni jednak funkcji instytucji nadzorczej, a jego wytyczne nie stanowią obowiązujących norm prawnych. 
instytucji finansowych na bazie przepisów dyrektywy 2006/46/WE ${ }^{19}$ Parlamentu Europejskiego i Rady z dnia 14 czerwca 2006 roku zmieniającej dyrektywy Rady 78/660/EWG w sprawie rocznych sprawozdań finansowych niektórych rodzajów spółek, 83/349/EWG w sprawie skonsolidowanych sprawozdań finansowych, 86/635/EWG w sprawie rocznych i skonsolidowanych sprawozdań finansowych banków i innych instytucji finansowych oraz 91/674/EWG w sprawie rocznych i skonsolidowanych sprawozdań finansowych zakładów ubezpieczeń ${ }^{20}$.

W świetle analizy zaprezentowanych definicji należy uznać, że interdyscyplinarny charakter systemu compliance niejako zmusza ustawodawcę unijnego oraz krajowego do tworzenia definicji z uwzględnieniem jak największego zakresu zarówno personalnego, jak i materialnego. Jest tak przede wszystkim dlatego, że ówczesny system compliance został znacząco rozbudowany, aby nie tylko dbać o zgodną z prawem działalność banku, lecz także spełniać funkcję nadzorczą, kontrolną oraz współdziałać z obszarami ryzyka operacyjnego, prawnego i audytu ${ }^{21}$.

\section{Akty prawne i soft law regulujące obszar compliance}

Zarządzanie instytucjami bankowymi obejmuje również zarządzanie ryzykami prawnymi, które stanowią immanentną część działalności banków. Przy pomocy Compliance Management System wspomniane ryzyko prawne powinno być minimalizowane, tak aby zapewnić zgodność działalności bankowej z obowiązującymi regulacjami prawnymi. Tworzenie systemu compliance odbywa się na podstawie obowiązujących przepisów prawa, dobrych praktyk oraz rekomendacji i wytycznych wydawanych za pośrednictwem insty tucji nadzorczych. Z uwagi na to, iż obszar compliance funkcjonujący w instytucjach finansowych ma zapewnić działalność zgodną z normami prawnymi i regulacjami nadzorczymi, warto zwrócić uwagę na konieczność podążania prawodawcy za rozwojem tej struktury odnoszącej się do coraz nowszych zagadnień.

Przy analizie treści regulacji dotyczących banków, a także instytucji finansowych w zakresie ich obowiązku zapewnienia zgodności można powziąć wniosek, iż całokształt tych regulacji należy podzielić na ${ }^{22}$ :

- regulacje ochrony rynków (financial wholesale regulations) dotyczące zaleceń skierowanych do struktury rynkowej, których nadrzędnym celem jest zagwarantowanie rozdziału pomiędzy podmiotami prowadzącymi działalność

19 Z kolei celem dyrektywy 2006/46/WE jest harmonizacja w zakresie treści i formatu rocznych sprawozdań finansowych, w tym również sprawozdań skonsolidowanych większości instytucji kredytowych oraz innych instytucji kredytowych w Unii Europejskiej, z pewnymi wyjątkami. Wyjątki w zakresie stosowania niniejszej dyrektywy występują w Grecji: ETEBA — Narodowy Bank Inwestycyjny Rozwoju Przemysłu, w Irlandii: Industrial and Provident Societies, w Zjednoczonym Królestwie - Friendly Societies oraz Industrial and Provident Societies.

20 Dz.Urz. UE L 224 z dnia 16 sierpnia 2006 roku, passim.

21 R. Jakubowski, op. cit., s. 63.

22 T. Braun, Unormowania compliance w korporacjach, Warszawa 2007, s. 78-79. 
w różnych obszarach ryzyka, tak aby w czasie problemów finansowych danego obszaru nadmierne powiązania nie doprowadziły do destabilizacji pozostałej części rynku ${ }^{23}$;

- regulacje ochrony akcjonariuszy (prudential regulations), czyli normy ostrożnościowe określające wewnętrzną procedurę banku, wedle których instytucja finansowa podejmuje działania związane z zarządzaniem różnego rodzaju ryzykiem $^{24}$;

- regulacje ochrony klientów (conduct regulations) odnoszące się stricte do działań podejmowanych przez banki w stosunku do klientów, którym oferowane są ich produkty finansowe ${ }^{25}$;

- regulacje ochrony systemu finansowego poprzez przeciwdziałanie praniu pieniędzy i korupcji (financial crime regulations) mające na celu wyeliminowanie działań zmierzających do wprowadzenia do obrotu pieniędzy pochodzących $\mathrm{z}$ działalności przestępczej ${ }^{26}$.

W polskim prawie podstawy w zakresie zapewnienia zgodności regulacji z prawem w obszarze bankowości tworzą przede wszystkim:

- ustawa z dnia 29 sierpnia 1997 roku Prawo bankowe ${ }^{27}$;

— ustawa z dnia 29 lipca 2005 roku o obrocie instrumentami finansowymi ${ }^{28}$ oraz rozporządzenia wydane na jej podstawie w zakresie dyrektywy MiFID II ${ }^{29}$;

- ustawa z dnia 1 marca 2018 roku o przeciwdziałaniu praniu pieniędzy i finansowaniu terroryzmu ${ }^{30}$.

23 Zob. raport High-level Expert Group on reforming the structure of the EU banking sector mający na celu zbadanie potrzeby strukturalnej reformy sektora bankowego w EU, https://ec.europa.eu/info/system/files/liikanen-report-02102012_en.pdf (dostęp: 20.09.2018).

24 Zob. dyrektywa Parlamentu Europejskiego i Rady 2013/36/UE z dnia 26 czerwca 2013 roku w sprawie warunków dopuszczenia instytucji kredytowych do działalności oraz nadzoru ostrożnościowego nad instytucjami kredytowymi i firmami inwestycyjnymi, zmieniająca dyrektywę 2002/87/ WE i uchylająca dyrektywy 2006/48/WE oraz 2006/49/WE (Dz.Urz. UE L 176 z dnia 27 czerwca 2013 roku, passim).

25 Zob. dyrektywa 2004/39/WE w sprawie rynków instrumentów finansowych, a także rozporządzenie delegowane Komisji (UE) nr 148/2013 z dnia 19 grudnia 2012 roku uzupełniające rozporządzenie Parlamentu Europejskiego i Rady UE nr 648/2012 w sprawie instrumentów pochodnych będących przedmiotem obrotu poza rynkiem regulowanym, kontrahentów centralnych i repozytoriów transakcji w odniesieniu do regulacyjnych standardów technicznych określających minimalny poziom szczegółowości informacji podlegających zgłoszeniu repozytorium transakcji (Dz.Urz. UE L 52 z dnia 23 lutego 2013 roku, s. 1, ze zm.).

26 Amerykańska ustawa w sprawie zachowania życia i wolności — The USA Patriot Act: Preserving Life and Liberty; amerykańska ustawa w sprawie praktyk korupcyjnych — The United States Foreign Corrupt Practices Act (Public Law No. 95-213, s. 306).

27 Tekst jedn. Dz.U. z 2017 r. poz. 1876; dalej: p.b.

28 Tekst jedn. Dz.U. z 2017 r. poz. 1768; dalej: u.o.i.f.

29 Dyrektywa Parlamentu Europejskiego i Rady 2014/65/UE z dnia 15 maja 2014 roku w sprawie rynków instrumentów finansowych oraz zmieniająca dyrektywę 2002/92/WE i dyrektywę 2011/61/ WE (Dz.Urz. UE L 173 z dnia 12 czerwca 2014 roku, passim; dalej: Dyrektywa MiFID II, MiFID II.

30 Dz.U. z 2018 r. poz. 723. 
Z kolei zbiór regulacji soft law, które nie mieszczą się w zamkniętym przedmiotowo katalogu źródeł prawa powszechnie obowiązującego w rozumieniu art. 87 Konstytucji RP, dotyczących kwestii ryzyka braku zgodności w bankowości, składa się między innymi z następujących dokumentów ${ }^{31}$ :

- uchwała KNF nr 258/2011 w sprawie szczegółowych zasad funkcjonowania systemu zarządzania ryzykiem i systemu kontroli wewnętrznej oraz szczegółowych warunków szacowania przez banki kapitału wewnętrznego i dokonywania przeglądów procesu szacowania i utrzymywania kapitału wewnętrznego oraz zasad ustalania polityki zmiennych składników wynagrodzeń osób zajmujących stanowiska kierownicze $\mathrm{w}$ banku ${ }^{32}$;

— rekomendacja H KNF dotycząca systemu kontroli wewnętrznej w bankach, jak również rekomendacja M KNF w sprawie zarządzania ryzykiem operacyjnym w bankach;

- wytyczne (Europejski Urząd Nadzoru Giełd i Papierów Wartościowych — ESMA $^{33}$ ) w zakresie funkcji compliance oraz oferowania produktów inwestycyjnych (MiFID);

- wytyczne i dobre praktyki zawarte w dokumencie Zgodność i funkcja zapewnienia zgodności w bankach, opracowanym przez Komitet Bazylejski ds. Nadzoru Bankowego;

- wytyczne w sprawie określonych aspektów wymogów dyrektywy MiFID, dotyczących komórki ds. nadzoru zgodności z prawem.

Należy zauważyć, że dyrektywa MiFID została częściowo przekształcona w dyrektywę MiFID II. Ów katalog źródeł prawa powszechnie obowiązujących oraz o charakterze wewnętrznym, dotyczących systemu compliance, składa się z aktów prawnych, a także rekomendacji i wytycznych, które w przeciwieństwie do aktów prawnych nie ustanawiają bezwzględnych obowiązków ${ }^{34}$. Nie można ich zaklasyfikować do katalogu aktów prawnie wiążących, w związku z czym $\mathrm{z}$ formalnego punktu widzenia nie mają one mocy obowiązującej ${ }^{35}$. W literaturze przedmiotu istnieje pogląd, zgodnie z którym dokumenty te stanowią przykład

31 Zamknięcie przedmiotowe katalogu źródeł prawa powszechnie obowiązującego oznacza, że prawodawca już na poziomie regulacji Konstytucji RP dokonał wyczerpującego wskazania wszystkich typów aktów prawa o charakterze powszechnie obowiązującym.

32 Dz.Urz. KNF Nr 11, poz. 42.

33 ESMA (ang. European Securities and Markets Authority) jest niezależnym organem UE, którego celem jest poprawa ochrony inwestorów oraz promowanie stabilnych i sprawnych rynków finansowych. Członkami są reprezentanci wszystkich właściwych krajowych organów nadzoru, każdy z prawem głosu. Polskę w Radzie Organów Nadzoru ESMA (ang. Board of Supervisors) reprezentuje Komisja Nadzoru Finansowego.

34 Zob. R. Bobkiewicz, Nadzór bankowy, Słupsk 2002, s. 124-125.

35 C. Kosikowski, Publiczne prawo bankowe, Warszawa 1999, s. 75. 
soft law ${ }^{36}$ par excellence ${ }^{37}$. Zgodnie z doktryną dokumenty zawierające normy ostrożnościowe należące przy tym do grona soft law w działalności bankowej klasyfikowane są jako źródła prawa w ujęciu funkcjonalnym ${ }^{38}$.

Jak wspomniano, można wyróżnić wiele rodzajów ryzyk związanych z brakiem zgodności w bankowości, jednak w niniejszej publikacji analizie poddano system compliance $\mathrm{w}$ kontekście ryzyka prawnego, w związku z czym warto zwrócić szczególną uwagę na kilka z przywołanych dokumentów.

Komisja Nadzoru Finansowego, mająca za zadanie podejmowanie działań w obszarze compliance między innymi poprzez podwyższanie efektywności stosowanych środków compliance jak do tej pory wydała jedynie rekomendacje w dziale $\mathrm{C}$ - Zapewnienie zgodności w ramach Rekomendacji $\mathrm{H}^{39}$, która jedynie pośrednio odnosi się do niezwykle istotnej problematyki, jaką jest ryzyko prawne. Omawiana rekomendacja zarówno dla banków, jak i instytucji finansowych stanowi jedynie zbiór zasad, wedle których winny postępować, zmierzając do właściwego zarządzania ryzykiem prawnym. Nie bez znaczenia jest to, że wspomniano również o Rekomendacji M KNF w sprawie zarządzania ryzykiem operacyjnym w bankach, ponieważ $\mathrm{w}$ zakres ryzyka operacyjnego wchodzi ryzyko prawne. Zgodnie z brzmieniem Rekomendacji

Bank powinien wyodrębnić zapewnianie zgodności jako jeden z czterech ogólnych celów systemu kontroli wewnętrznej. Bank powinien zapewniać zgodność poprzez funkcję kontroli oraz zarządzanie ryzykiem braku zgodności ${ }^{40}$.

W świetle dynamicznego rozwoju rynku finansowego, chociażby w dziedzinie walut cyfrowych, słuszne wydawałoby się podjęcie działań przez KNF w zakresie nowelizacji rekomendacji odnoszącej się do ryzyka prawnego, tak aby podążać za powstającymi regulacjami prawnymi. Wydaje się, że dotychczas podejmowane działania zmierzające do publikowania jedynie komunikatów dotyczących ryzyk prawnych i okołoprawnych są niewystarczające, aby właściwie zadbać o sferę braku zgodności w bankowości.

36 Na temat roli norm o charakterze soft law w regulacjach prawa bankowego zob. R. Kaszubski, Funkcjonalne źródła prawa bankowego publicznego, Warszawa 2006, s. 18 n.; M. Olszak, Bankowe normy ostrożnościowe, Białystok 2012, s. 295 n.; Z. Ofiarski, Rola soft law w regulacji rynku finansowego na przykładzie rekomendacji i wytycznych Komisji Nadzoru Finansowego, [w:] Prawo rynku finansowego. Doktryna, instytucje, praktyka, red. A. Jurkowska-Zeidler, M. Olszak, Warszawa 2016, s. 137-158.

37 Zob. R. Cranston, Principles of Banking Law, Oxford 2006, s. 64; M. Olszak, op. cit., s. 95.

38 Szerzej R. Kaszubski, op. cit., s. 32 n.

39 Rekomendacja ta została wydana na podstawie art. 137 ust. 1 pkt 5 ustawy z dnia 29 sierpnia 1997 roku Prawo bankowe (Dz.U. z 2016 r. poz. 1988 ze zm.) i art. 11 ust. 1 oraz art. 67 ust. 2 ustawy z dnia 21 lipca 2006 roku o nadzorze nad rynkiem finansowym (Dz.U. z 2017 r. poz. 196 z późn. zm.).

40 Zob. rekomendacje $\mathrm{H}$ dotyczącą systemu kontroli wewnętrznej w bankach, wydaną przez KNF, https://bip.knf.gov.pl/pliki/Rekomendacja_H_2017_60471_tcm6-60471.pdf (dostęp: 11.09.2018). 
Należy także wskazać, że samodzielny organ, jakim jest Europejski Urząd Nadzoru Giełd i Papierów Wartościowych, wydał wytyczne mające zastosowanie szczególnie do firm inwestycyjnych ${ }^{41} \mathrm{w}$ sprawie określonych aspektów wymogów dyrektywy MiFID I, dotyczących komórki ds. nadzoru zgodności z prawem. Wytyczne te mają na celu szersze omówienie zasad stosowania wybranych aspektów wymogów dyrektywy MiFID I w zakresie obszaru niezgodności z prawem, tak aby zagwarantować powszechne oraz spójne zastosowanie art. 13 dyrektywy w sprawie rynków instrumentów finansowych (MiFID I) oraz art. 6 dyrektywy wykonawczej do dyrektywy MiFID I ${ }^{42}$. Co więcej, „kluczem” do zapewnienia zgodności ze standardami regulacyjnymi wydaje się właściwe podejście organów nadzorczych do wymogów MiFID I dotyczących komórki ds. nadzoru zgodności z prawem, tak aby zapewnić większą użyteczność istniejących już standardów.

Istnieje kilka koncepcji relacji, jaka występuje pomiędzy systemem kontroli wewnętrznej i funkcji zarządzania ryzykiem braku zgodności w bankowości. Pozostając w obszarze regulacji europejskich i krajowych, warto zwrócić uwagę na tożsamość przyjętych przesłanek zakładających relację rozłączności między systemem kontroli wewnętrznej a funkcją compliance, co znajduje odzwierciedlenie w art. 22 dyrektywy CRD, jak również w art. 74 oraz 88 ust. 1 b dyrektywy CRD $\mathrm{IV}^{43}$ oraz wytycznych Europejskiego Urzędu Nadzoru Bankowego - EUNB (EBA - European Banking Authority), lecz także w dyrektywie 2006/43/EC oraz dyrektywie 2006/46/EC744. Należy zauważyć, że w ramach ustawodawstwa kra-

41 Firm inwestycyjnych (zgodnie z definicją w art. 4 ust. 1 pkt 1 dyrektywy MiFID II), w tym instytucji kredytowych świadczących usługi inwestycyjne i spółek zarządzających funduszem typu UCITS, oraz do właściwych organów. Niniejsze wytyczne mają zastosowanie do spółek zarządzających UCITS tylko wtedy, gdy świadczą one usługi inwestycyjne indywidualnego zarządzania portfelem lub doradztwa inwestycyjnego (w rozumieniu art. 6 ust. 3 lit. a) i b) dyrektywy w sprawie UCITS).

42 Zob. wytyczne w sprawie określonych aspektów wymogów dyrektywy MiFID dotyczących komórki ds. nadzoru zgodności z prawem, https://forumcompliance.com/wp-content/uploads/2016/06/esma-compliance-2012-388_pl.pdf (dostęp: 15.09.2018).

43 Odpowiednio dyrektywa 2006/48/WE Parlamentu Europejskiego i Rady z dnia 14 czerwca 2006 roku w sprawie podejmowania i prowadzenia działalności przez instytucje kredytowe (wersja przeredagowana); dyrektywa Parlamentu Europejskiego i Rady 2013/36/UE z dnia 26 czerwca 2013 roku w sprawie warunków dopuszczenia instytucji kredytowych do działalności oraz nadzoru ostrożnościowego nad instytucjami kredytowymi i firmami inwestycyjnymi, zmieniająca dyrektywę 2002/87/WE i uchylająca dyrektywy 2006/48/WE oraz 2006/49/WE (Capital Requirements Directive IV, CRD IV) (Dz.Urz. UE L 176 z dnia 27 czerwca 2013 roku).

44 Dyrektywa 2006/43/WE Parlamentu Europejskiego i Rady z dnia 17 maja 2006 roku w sprawie ustawowych badań rocznych sprawozdań finansowych i skonsolidowanych sprawozdań finansowych, zmieniająca dyrektywy Rady 78/660/ EWG i 83/349/EWG oraz uchylająca dyrektywę Rady 84/253/EWG; dyrektywa 2006/46/WE Parlamentu Europejskiego i Rady z dnia 14 czerwca 2006 roku zmieniająca dyrektywy Rady 78/660/EWG w sprawie rocznych sprawozdań finansowych niektórych rodzajów spółek, 83/349/EWG w sprawie skonsolidowanych sprawozdań finansowych, 86/635/EWG w sprawie rocznych i skonsolidowanych sprawozdań finansowych banków 
jowego na wspomnianą relację rozłączności wskazuje art. 9 ust. 3 ustawy Prawo bankowe. Zgodnie z jego treścią w ramach systemu zarządzania w banku funkcjonuje co najmniej system zarządzania ryzykiem i system kontroli wewnętrznej.

W świetle znaczenia systemu compliance oraz jego umiejscowienia w strukturze wewnętrznej banku warto zwrócić uwagę, że Komitet Bazylejski Nadzoru Bankowego rekomendował, by nadzór nad zarządzaniem ryzykiem braku zgodności pełniła rada nadzorcza banku, zarząd banku zaś ponosił odpowiedzialność za bieżące wykonywanie czynności związanych z obszarem compliance oraz sprawował pieczę nad systematycznym przeglądem zgodności działań podejmowanych przez bank w stosunku do obowiązujących norm. Niewątpliwie zaangażowanie najwyższych organów instytucji bankowych w działalność systemu compliance przyczyniło się do nadania właściwej rangi procesowi związanemu z zarządzaniem ryzykiem braku zgodności w systemie bankowym.

\section{3. Środki compliance - czyli instytucja whistleblowing}

Efektywne funkcjonowanie struktury Compliance Management System, której celem jest zapewnienie zgodności, powinno opierać się na stosowaniu szerokiego spektrum dostępnych środków compliance. Katalog środków jest zróżnicowany, ich właściwy dobór powinien zaś być uzależniony od kilku czynników: obszaru działalności podmiotu, wielkości podmiotu, branży, stopnia internacjonalizacji 45 .

Instytucja whistleblowing należy do kategorii środków zorientowanych na wykrywanie i sankcjonowanie naruszeń. Niewątpliwie aktem prawnym wzmacniającym pozycję funkcji zarządzania ryzykiem braku zgodności jest wspomniana dyrektywa CRD IV. Oprócz zmian w zakresie wzmocnienia statusu kierownika funkcji zarządzania ryzykiem oraz większej niezależności funkcji związanych z zarządzaniem ryzykiem od realizacji zadań operacyjnych wprowadza ona również zmiany w krajowym porządku prawnym w zakresie instytucji whistleblowing.

Z punktu widzenia stabilności systemu finansowego oraz powszechności wdrożenia funkcji whistleblowing kluczowm momentem było implementowanie przez ustawodawcę art. 71 dyrektywy CRD IV, w myśl którego wprowadzono obowiązkowy system anonimowego zgłaszania naruszeń, czyli whistleblowing. Do czasu wprowadzenia tych zmian do omawianej kwestii odnosił się $§ 6$ dokumentu opublikowanego przez KNF Zasady ładu korporacyjnego ${ }^{46}$, zgodnie z którym whistleblowing był fakultatywny, w związku z czym instytucje finansowe mogły

i innych instytucji finansowych oraz 91/674/ EWG w sprawie rocznych i skonsolidowanych sprawozdań finansowych zakładów ubezpieczeń (Dz.Urz. UE L 157 z dnia 9 czerwca 2006 roku).

45 J. Burkle, Corporate Compliance - Pflicht oder Kur den Vorstand der AG?, „, Der Betriebs-Berater" 2005 , nr 11, s. 565.

46 Zob. Zasady Ładu Korporacyjnego dla Instytucji Nadzorowanych, KNF 22 lipca 2014 roku, https://www.knf.gov.pl/knf/pl/komponenty/img/knf_140904_Zasady_ladu_korporacyjnego_22072014_38575.pdf(dostęp: 18.09.2018). 
zrezygnować z jego wprowadzania bez względu na to, czy mają miejsce okoliczności zezwalające na wyłączenie stosowania Zasad ładu korporacyjnego chociażby z uwagi na przesłankę nadmiernej uciążliwości.

Należy podkreślić, że dokument wydany przez KNF — Zasady ładu korporacyjnego - nie wprowadził obowiązku utworzenia struktury odpowiedzialnej za anonimowe zgłaszanie naruszeń, na gruncie polskiego ustawodawstwa po raz pierwszy ustalono ramy prawne określające podejmowanie takich działań w przyszłości. Wydaje się jednak, iż pozostawienie pewnej dowolności w tej materii przez instytucje nadzorcze nie przyczyniało się do rewolucji w zakresie wdrażania instytucji whistleblowing.

Zgodnie $\mathrm{z}$ art. 9 ust. 2a Prawo bankowe ustawodawca nałożył na bank obowiązek zapewnienia anonimowości osobie zawiadamiającej. Niewątpliwie właściwe zapewnienie anonimowości osobie zawiadamiającej o naruszeniach stanowi jeden z kluczowych elementów pozwalających na efektywne stosowanie instytucji whistleblowing. Osoba zawiadamiająca mająca świadomość ułomności działania systemu zapewniającego anonimowość może skutecznie odstąpić od podejmowania działań zmierzających do ujawnienia nieprawidłowości występujących w instytucji finansowej.

W myśl § 45 ust. 3 rozporządzenia Ministra Rozwoju i Finansów z dnia 6 marca 2017 roku w sprawie systemu zarządzania ryzykiem i systemu kontroli wewnętrznej, polityki wynagrodzeń oraz szczegółowego sposobu szacowania kapitału wewnętrznego w bankach ${ }^{47}$ bank ma za zadanie zapewnić możliwość zgłaszania przez pracowników naruszeń za pośrednictwem specjalnego, niezależnego oraz autonomicznego kanału komunikacji. Do prawidłowego działania instytucji whistleblowing konieczne jest, aby katalog mechanizmów umożliwiających przekazywanie informacji o nieprawidłowościach był dopasowany do kultury organizacyjnej danej instytucji finansowej.

Co do osoby nabywającej ochronę oraz uprawnionej do dokonania zgłoszenia naruszenia w literaturze naukowej pozostawał spór na gruncie ustawy Prawo bankowe. W świetle art. 9 ust. $2 \mathrm{~b}$ Prawo bankowe nierozwiązana pozostawała kwestia, czy skoro w ramach procedur, o których mowa w ust. 2a, bank zapewnia pracownikom ochronę, to zgłoszeń mogą dokonywać wyłącznie pracownicy jako jedyne podmioty nabywające ochronę w związku z dokonanym zgłoszeniem w ramach instytucji whistleblowing. Niejednoznaczność wynika z treści owego przepisu, który nie odnosi się do kwestii podmiotów uprawnionych do dokonania zgłoszenia, lecz jedynie wskazuje komu jest zagwarantowana ochrona ze strony banku. W tym kontekście interpretacji wymagałoby również pojęcie pracownika banku, ponieważ w literaturze, na gruncie art. 107 Prawo bankowe, wskazuje się wątpliwości w tej materii, tak więc niewykluczona pozostaje możliwość zastosowania wykładni rozszerzającej.

47 Dz.U. z 2017 r. poz. 637, dalej: rozporządzenie ws. zarządzania ryzykiem. 
We wspomnianym rozporządzeniu w sprawie zarządzania ryzykiem ustawodawca podtrzymał zaprezentowane stanowisko dotyczące podmiotów objętych ochroną banku w sytuacji zgłoszenia naruszeń. Co więcej, zgodnie $§ 45$ ust. 1 rozporządzenia w sprawie zarządzania ryzykiem „Bank opracowuje i wdraża procedury anonimowego zgłaszania przez pracowników naruszeń prawa [...]”. Na gruncie $\S 45$ n. rozporządzenia w sprawie zarządzania ryzykiem wydaje się zasadne wysnucie tezy, iż jedynymi podmiotami uprawnionymi do zgłaszania naruszeń są pracownicy banku oraz jako jedyni korzystają oni z ustawowego uprawnienia do ochrony przed działaniami o charakterze represyjnym, dyskryminacją lub innymi rodzajami niesprawiedliwego traktowania.

\section{Zakończenie}

Przeprowadzone w ramach niniejszego artykułu rozważania pozwalają na sformułowanie wniosku, iż w ciągu ostatnich lat dokonał się istotny postęp w nadawaniu właściwej rangi systemowi compliance. Rozważania w kwestii ryzyka braku zgodności pojawiają w wielu aktach prawnych oraz w regulacjach soft law. Jednak do skutecznego działania środków compliance, czyli chociażby instytucji whistleblowing, konieczny jest dalszy postęp w rozwijaniu kultury organizacyjnej banków oraz instytucji finansowych. Gwarancją właściwego funkcjonowania systemu compliance jest efektywne wykorzystywanie dostępnych atrybutów, to jest instytucji whistleblowing. Ze względu na to, iż współczesną bankowość charakteryzuje głęboki stopień uregulowania, konieczne stało się poszerzenie zakresu obowiązków systemu compliance w bankach.

De lege ferenda ustawodawcy państw członkowskich Unii Europejskiej stoją przed wyzwaniem zapewnienia właściwego reżimu prawnego pozwalającego na prawidłowe funkcjonowanie systemu compliance, który jest warunkiem prowadzenia działalności w zgodzie z przepisami i zaleceniami nadzorczymi. Jednak należy mieć na uwadze, iż system compliance to pożądany stan zgodności z przepisami oraz regulacjami soft law, który sam w sobie nie gwarantuje bezpieczeństwa oraz nie daje rękojmi wyeliminowania potencjalnego ryzyka niezgodności.

Działania podejmowane przez banki będące podmiotami zaufania publicznego niewątpliwie dążą do eliminowania lub ograniczania ryzyka braku zgodności, rozwijając w ramach swojej struktury system compliance mający zapewnić również bezpieczeństwo klientów banku.

\section{Bibliografia}

Barcik A., Mechanizm compliance — pytanie o miejsce i zasadność w strategiach csr współczesnych organizacji, „Prace naukowe Uniwersytetu Ekonomicznego we Wrocławiu” 2016, nr 419.

Bleker S., Hortensius D., ISO 19600: The development of a global standard on compliance management, „Business Compliance” 2014, nr 2.

Bobkiewicz R., Nadzór bankowy, Słupsk 2002. 
Braun T., Unormowania compliance w korporacjach, Warszawa 2007.

Burkle J., Corporate Compliance — Pflicht oder Kur den Vorstand der AG?, „Der Betriebs-Berater” 2005, nr 11.

Cichy Ł., Funkcja compliance w bankach, Warszawa 2015.

Cichy Ł., Whistleblowing w bankach, Warszawa 2017.

Cranston R., Principles of Banking Law, Oxford 2006.

Cyman D., Instytucja finansowa, [w:] Leksykon prawa finansowego. 100 podstawowych pojęć, red. A. Drwiłło, D. Maśniak, Warszawa 2009.

Jagura B., Rola organów spótki kapitałowej w realizacji funkcji compliance, Warszawa 2017.

Jagura B., Szarowicz T., Prawne podstawy systemów zarządzania compliance w prawie niemieckim i polskim, „Controlling” 2014, nr 3-4.

Jakubowski R., Rozwój funkcji compliance w polskim sektorze bankowym, „Monitor Prawa Bankowego" 2013, nr 11.

Kaszubski R., Funkcjonalne źródła prawa bankowego publicznego, Warszawa 2006.

Kosikowski C., Publiczne prawo bankowe, Warszawa 1999.

Makowicz B., Compliance w przedsiębiorstwie, Warszawa 2011.

Near J.P., Miceli M.P., Organizational Dessidence: The Case of Whistle-blowing, „Journal of BusinessEthics" 1985, nr 4.

Ofiarski Z., Rola soft law $w$ regulacji rynku finansowego na przyktadzie rekomendacji $i$ wytycznych Komisji Nadzoru Finansowego, [w:] Prawo rynku finansowego. Doktryna, instytucje, praktyka, red. A. Jurkowska-Zeidler, M. Olszak, Warszawa 2016.

Olszak M., Bankowe normy ostrożnościowe, Białystok 2012.

Paluchniak C., Definicja ryzyka prawnego w bankowości oraz krytyczna ocena rekomendacji $H$ Komisji Nadzoru Finansowego, „Nauki o Finansach” 2015, nr 3.

Pape J., Corporate Compliance - Rechtspflichten zur Verhaltenssteuerung von Unternehmensangenhorigen in Deutshland und den USA, Berlin 2011.

Rogowski W., Whistleblowing: bohaterstwo, zdrada czy interes?, „Przegląd Corporate Governance” 2007, nr 1 (9).

Schneider U., Compliance als Aufgabe der Unternehmensleitung, Zeitschrift für Wirtschaftsrecht und Insolvenzpraxis, ZIP 2003.

Zapadka P., Definicja legalna instytucji finansowej w polskim systemie prawnym - wybrane zagadnienia, „Prawo Bankowe” 2005, nr 9.

Zdanowicz B., Compliance — nowa funkcja banków, „Bezpieczny Bank” 2004, nr 1 (22).

\section{Źródła internetowe}

https://www.bis.org/publ/bcbs103.htm.

Compliance matter. What companies can do better to respect EU competition rules, European Commission. Competition, Special first edition, Belgium 2011, https://publications.europa.eu/en/ publication-detail/-/publication/78f46c48-e03e-4c36-bbbe-aa08c2514d7a/language-en.

Raport High-level Expert Group on reforming the structure of the EU banking sector mający na celu zbadanie potrzeby strukturalnej reformy sektora bankowego w EU, https://ec.europa.eu/info/ system/files/liikanen-report-02102012_en.pdf.

Rekomendacja $\mathrm{H}$ dotycząca systemu kontroli wewnętrznej w bankach, wydana przez KNF, https:// bip.knf.gov.pl/pliki/Rekomendacja_H_2017_60471_tcm6-60471.pdf.

Sprawozdanie zarządu z działalności Grupy Kapitałowej PKO Banku Polskiego SA za 2015 rok, https://www.pkobp.pl/media_files/18d10e93-dd69-4ab7-8839-0fa406cc4343.pdf.

Wytyczne w sprawie określonych aspektów wymogów dyrektywy MiFID dotyczących komórki ds. nadzoru zgodności z prawem, https://forumcompliance.com/wp-content/uploads/2016/06/esma-compliance-2012-388_pl.pdf.

Studenckie Prace Prawnicze, Administratywistyczne i Ekonomiczne 27, 2019

(C) for this edition by CNS 
Zasady Ładu Korporacyjnego dla Instytucji Nadzorowanych, KNF 22 lipca 2014 r., https://www.knf. gov.pl/knf/pl/komponenty/img/knf_140904_Zasady_ladu_korporacyjnego_22072014_38575.pdf.

\section{Źródła prawa}

\section{Polskie akty prawne}

Ustawa z dnia 29 sierpnia 1997 roku Prawo bankowe (tekst jedn. Dz.U. z 2018 r. poz. 2187).

Ustawa z dnia 29 lipca 2005 roku o obrocie instrumentami finansowymi (tekst jedn. Dz.U. z 2018 r. poz. 2286).

Ustawa z dnia 21 lipca 2006 roku o nadzorze nad rynkiem finansowym (Dz.U. z 2018 r. poz. 621).

Uchwała nr 258/2011 Komisji nadzoru finansowego z dnia 4 października 2011 roku w sprawie szczegółowych zasad funkcjonowania systemu zarządzania ryzykiem i systemu kontroli wewnętrznej oraz szczegółowych warunków szacowania przez banki kapitału wewnętrznego i dokonywania przeglądów procesu szacowania i utrzymywania kapitału wewnętrznego oraz zasad ustalania polityki zmiennych składników wynagrodzeń osób zajmujących stanowiska kierownicze w banku (Dz.Urz. KNF Nr 11, poz. 42).

Rozporządzenie Ministra Rozwoju i Finansów z dnia 6 marca 2017 roku w sprawie systemu zarządzania ryzykiem i systemu kontroli wewnętrznej, polityki wynagrodzeń oraz szczegółowego sposobu szacowania kapitału wewnętrznego w bankach (Dz.U. z 2017 r. poz. 637).

Ustawa z dnia 1 marca 2018 roku o przeciwdziałaniu praniu pieniędzy oraz finansowaniu terroryzmu (Dz.U z 2018 r. poz. 723).

\section{Europejskie akty prawne}

Dyrektywa 2004/39/WE w sprawie rynków instrumentów finansowych, a także rozporządzenie delegowane Komisji (UE) nr 148/2013 z dnia 19 grudnia 2012 roku uzupełniające rozporządzenie Parlamentu Europejskiego i Rady UE nr 648/2012 w sprawie instrumentów pochodnych będących przedmiotem obrotu poza rynkiem regulowanym, kontrahentów centralnych i repozytoriów transakcji w odniesieniu do regulacyjnych standardów technicznych określających minimalny poziom szczegółowości informacji podlegających zgłoszeniu repozytorium transakcji (Dz.Urz. UE L 52 z dnia 23 lutego 2013 roku).

Dyrektywa 2006/43/WE Parlamentu Europejskiego i Rady z dnia 17 maja 2006 roku w sprawie ustawowych badań rocznych sprawozdań finansowych i skonsolidowanych sprawozdań finansowych, zmieniająca dyrektywy Rady 78/660/ EWG i 83/349/EWG oraz uchylająca dyrektywę Rady 84/253/EWG (Dz.Urz. UE L 157 z dnia 9 czerwca 2016 roku).

Dyrektywa 2006/46/WE Parlamentu Europejskiego i Rady z dnia 14 czerwca 2006 roku zmieniająca dyrektywy Rady 78/660/EWG w sprawie rocznych sprawozdań finansowych niektórych rodzajów spółek, 83/349/EWG w sprawie skonsolidowanych sprawozdań finansowych, 86/635/ EWG w sprawie rocznych i skonsolidowanych sprawozdań finansowych banków i innych instytucji finansowych oraz 91/674/EWG w sprawie rocznych i skonsolidowanych sprawozdań finansowych zakładów ubezpieczeń (Dz.Urz. UE L 224 z dnia 16 sierpnia 2006 roku).

Rozporządzenie Parlamentu Europejskiego i rady (UE) nr 575/2013 z dnia 26 czerwca 2013 roku w sprawie wymogów ostrożnościowych dla instytucji kredytowych i firm inwestycyjnych, zmieniające rozporządzenie (UE) nr 648/2012 (Dz. Urz. UE L 176 z dnia 27 czerwca 2013 roku).

Dyrektywa Parlamentu Europejskiego i Rady 2013/36/UE z dnia 26 czerwca 2013 roku w sprawie warunków dopuszczenia instytucji kredytowych do działalności oraz nadzoru ostrożnościowego nad instytucjami kredytowymi i firmami inwestycyjnymi, zmieniająca dyrektywę 2002/87/WE i uchylająca dyrektywy 2006/48/WE oraz 2006/49/WE (Dz. Urz. UE L 176 z dnia 27 czerwca 2013 roku). 
Dyrektywa Parlamentu Europejskiego i Rady 2014/65/UE z dnia 15 maja 2014 roku w sprawie rynków instrumentów finansowych oraz zmieniająca dyrektywę 2002/92/WE i dyrektywę 2011/61/ WE (Dz.Urz. UE L 173 z dnia 12 czerwca 2014 roku).

Rozporządzenie Parlamentu Europejskiego i Rady (UE) 2016/679 z dnia 27 kwietnia 2016 roku w sprawie ochrony osób fizycznych w związku z przetwarzaniem danych osobowych i w sprawie swobodnego przepływu takich danych oraz uchylenia dyrektywy 95/46/WE (Dz.Urz. UE L 119 z dnia 4 maja 2016 roku).

\section{Compliance risk in the banking system and institutions of whistleblowing}

\section{Summary}

In this article, the author attempts to present and examine compliance risk in banking and institutions of whistleblowing by explaining the concept of "compliance risk" and then indicating the legal acts and regulation of "soft law" in this regard. Undoubtedly, the development in the area of systematization of duties and rights, as well as giving the compliance system proper rank in the internal structure is the essence of correct management of compliance risk in banking. The definitions of compliance risk have an interdisciplinary character, therefore the EU and the national legislator are forced to create definitions taking into account the largest possible scope, both personal and material. Undoubtedly, the involvement of banking sector bodies in the compliance system and the ever-wider scope of legal acts and soft law regulations in this area have contributed to the appropriate ranking of the compliance risk management process in the banking system. The effective use of the available attributes, that is, the whistleblowing institution, guarantees the proper functioning of the compliance system. The whistleblowing institution is an example of preventive activity that can guard against violations of legal regulations. 